\title{
Movements and Area Use of Belugas, Delphinapterus leucas, in a Subarctic Alaskan Estuary
}

\author{
R.C. HOBBS,${ }^{1}$ K.L. LAIDRE,${ }^{2}$ D.J. VOS,${ }^{3}$ B.A. MAHONEY ${ }^{3}$ and M. EAGLETON ${ }^{3}$
}

(Received 8 November 2004; accepted in revised form 30 March 2005)

\begin{abstract}
Seasonal movements of 14 belugas in Cook Inlet, Alaska, were monitored by satellite telemetry between July and March in 2000-03. Whales used waters in the upper Cook Inlet intensively between summer and late autumn and dispersed to mid-inlet offshore waters during winter months. All whales remained in Cook Inlet the entire time they were tracked, and several whales were tracked through March. During summer and early fall, movements were clearly concentrated in specific areas, generally river mouths or bays, where whales were likely feeding on fish runs. Average daily travel distances ranged from 11 to $30 \mathrm{~km}$ per day. Monthly home ranges, estimated using the $95 \%$ kernel probability distribution of average daily positions, were smallest in August $\left(982 \mathrm{~km}^{2}\right.$ ), increased throughout autumn, and peaked in winter (reaching approximately $5000 \mathrm{~km}^{2}$ ). The seasonal variation in distribution and movement patterns displayed by belugas in Cook Inlet affect the sighting rates and seasonal abundance estimates obtained for this depleted population.
\end{abstract}

Key words: Alaska, beluga, Cook Inlet, Delphinapterus leucas, estuary, satellite tag, white whale

RÉSUMÉ. Les déplacements saisonniers de 14 bélugas du détroit de Cook, en Alaska, ont fait l'objet d'une surveillance au moyen d'un émetteur par satellite entre les mois de juillet et mars 2000 à 2003. Cela a permis de remarquer que les baleines se tenaient beaucoup dans les eaux de la partie supérieure du détroit de Cook de l'été jusqu'à la fin de l'automne, mais qu'elles se dispersaient dans les eaux du large du milieu du détroit pendant les mois d'hiver. Toutes les baleines sont restées dans le détroit de Cook pendant toute la durée de surveillance, et plusieurs baleines ont été suivies jusqu'au mois de mars. L'été et au début de l'automne, les déplacements étaient nettement concentrés dans des endroits spécifiques, généralement dans les embouchures ou les baies, où les baleines se nourrissaient probablement de poissons. En moyenne, les baleines se déplaçaient sur des distances variant de 11 à $30 \mathrm{~km}$ par jour. C'est en août que le domaine vital mensuel, estimé par la méthode du noyau en fonction d'une densité de probabilité de $95 \%$ des positions quotidiennes moyennes, était le plus petit $\left(982 \mathrm{~km}^{2}\right)$, après quoi il augmentait à l'automne et culminait l'hiver (où il atteignait environ $5000 \mathrm{~km}^{2}$ ). La variation saisonnière caractérisant la répartition et les déplacements des bélugas dans le détroit de Cook exerce une influence sur le taux d'observations et sur les estimations d'abondance saisonnière obtenues pour cette population en déclin.

Mots clés: Alaska, béluga, détroit de Cook, Delphinapterus leucas, estuaire, émetteur par satellite, baleine blanche

Traduit pour la revue Arctic par Nicole Giguère.

\section{INTRODUCTION}

Belugas (Delphinapterus leucas) in Cook Inlet are the most geographically and genetically isolated of the five stocks recognized around Alaska (O'Corry-Crowe et al., 1997; Ferrero et al., 2000). This isolation, in combination with their tendency toward site fidelity in summer (Rugh et al., 2000), makes them particularly vulnerable to both environmental and anthropogenic impacts (Hill, 1996; Moore et al., 2000). Between 1994 and 1998, the Cook Inlet beluga population declined by nearly $50 \%$ to an estimated 347 whales (coefficient of variation [CV] 0.29) (Hobbs et al., 2000). The Native subsistence hunt of approximately 70 whales per annum in Cook Inlet (Mahoney and Shelden, 2000), believed to be responsible for the decline, virtually ceased in 1999, and since then abundance appears to have stabilized. The population was estimated at 368 (CV 0.20) whales in 2004 (R. Hobbs, NMFS, unpubl. survey data). The population is now listed as depleted under the U.S. Marine Mammal Protection Act (Federal Register 65:34590-34597).

Belugas are seen in Cook Inlet in all months of the year (Rugh et al., 2000); however, their distribution outside the summer months is not well known (Huntington, 2000). Aerial surveys conducted in Cook Inlet from 1993 to 2002 routinely documented the distribution of belugas during June and July, when the whales remain in dense groups in the northern part of Cook Inlet, concentrated near shallow, low-salinity river outflows (Rugh et al., 2000). Belugas are observed to remain in these dense groups through

\footnotetext{
${ }^{1}$ National Marine Mammal Laboratory, Alaska Fisheries Science Center, National Marine Fisheries Service, 7600 Sand Point Way N.E., Seattle, Washington 98115, U.S.A.; Rod.Hobbs@noaa.gov

${ }^{2}$ Greenland Institute of Natural Resources, Box 570, DK-3900 Nuuk, Greenland.

${ }^{3}$ Alaska Regional Office, National Marine Fisheries Service, 222 W. 7th Avenue, Box 43, Anchorage, Alaska 99513, U.S.A.

(C) The Arctic Institute of North America
} 
TABLE 1. Information on beluga whales tagged in Cook Inlet, Alaska, between 2000 and 2002. Duration is the number of days between the tagging event and the last good-quality position.

\begin{tabular}{|c|c|c|c|c|c|c|c|c|}
\hline Whale ID & Date Tagged & $\begin{array}{c}\text { Date of } \\
\text { Last Position }\end{array}$ & Tag Model & $\begin{array}{c}\text { Duration of } \\
\text { Tracking (days) }\end{array}$ & Sex & $\begin{array}{l}\text { Body Length } \\
(\mathrm{cm})\end{array}$ & $\begin{array}{l}\text { Fluke Width } \\
\quad(\mathrm{cm})\end{array}$ & Color \\
\hline CI-0001 & 09/13/00 & 01/03/01 & ST16 & 112 & M & 413 & NA & white \\
\hline CI-0002 & 09/13/00 & 01/16/01 & ST16 & 125 & $\mathrm{~F}$ & 272 & NA & white/gray \\
\hline CI-0101 & $08 / 10 / 01$ & $12 / 09 / 01$ & Spot 2 & 121 & $\mathrm{~F}$ & 257 & 63 & gray \\
\hline CI-0102 & $08 / 11 / 01$ & $11 / 26 / 01$ & Spot 2 & 107 & M & 323 & 90 & white \\
\hline CI-0103 & 08/12/01 & $12 / 20 / 01$ & Spot 2 & 130 & $\mathrm{~F}$ & 312 & 78 & white \\
\hline CI-0105 & 08/13/01 & $12 / 26 / 01$ & Spot 2 & 135 & $\mathrm{~F}$ & 357 & 82 & white \\
\hline CI-0106 & $08 / 15 / 01$ & $11 / 17 / 01$ & ST16 & 94 & $\mathrm{~F}$ & 401 & 107 & white \\
\hline CI-0107 & $08 / 20 / 01$ & $03 / 09 / 02$ & ST16 & 201 & M & 442 & 189 & white \\
\hline CI-0201 & $07 / 29 / 01$ & $10 / 31 / 01$ & ST16 & 94 & M & 412 & 99 & white \\
\hline CI-0203 & $07 / 31 / 02$ & $08 / 24 / 02$ & ST16 & 24 & $\mathrm{~F}$ & 367 & 81 & white \\
\hline CI-0205 & $08 / 02 / 02$ & $03 / 30 / 03$ & ST16 & 240 & M & 390 & 90 & white/gray \\
\hline CI-0206 & $08 / 03 / 02$ & $03 / 20 / 03$ & ST16 & 229 & M & 355 & 84 & white/gray \\
\hline CI-0207 & $08 / 03 / 02$ & $08 / 05 / 02$ & ST16 & 2 & $\mathrm{~F}$ & 374 & 85 & white \\
\hline CI-0208 & $08 / 04 / 02$ & $03 / 30 / 03$ & ST16 & 238 & M & 375 & 93 & white/gray \\
\hline
\end{tabular}

August and are presumably feeding on Pacific salmon (Oncorhynchus spp.) and other fish runs (Moore et al., 2000). Monthly surveys indicate that at least some belugas remain in upper Cook Inlet through autumn, yet a substantial drop in sighting rates occurs sometime around November (Rugh et al., 2004). It has been suggested that belugas disperse into the Gulf of Alaska in winter (Calkins, 1983; Hubbard et al., 1999) because fewer sightings are reported in the upper inlet in winter months. Surveys for belugas in February-March 1997 encountered small, scattered pods in the central part of the inlet (Hanson and Hubbard, 1999), and numerous opportunistic sightings have been reported throughout the year (R. Hobbs, NMFS, unpubl. survey data). Sightings of belugas in the Gulf of Alaska and adjacent inside waters are considered rare $(<30)$ relative to the more than $150000 \mathrm{~km}$ of survey effort and the many thousands of non-beluga cetacean sightings documented for the region during the past 30 years (Laidre et al., 2000).

Satellite telemetry has proven to be a useful tool for monitoring the movements and dive behavior of belugas (Martin and Smith, 1992, 1999; Heide-Jørgensen et al., 1998; Richard et al., 1998; Kingsley et al., 2001; Martin et al., 2001; Suydam et al., 2001). The decrease in the size of tags (mounted on the dorsal ridge) and the increase in tag longevity (both battery life and attachment time) have facilitated the remote and continuous collection of data from individual whales for many months at a time. In this study, we monitored the movements of belugas tagged in Cook Inlet in mid to late summer during 2000-02 and used the satellite telemetry data to define wintering areas and examine monthly patterns of area use. We examined information on whale movements obtained from August through March to assess seasonal variation in physical and biological features of Cook Inlet, Alaska.

\section{MATERIALS AND METHODS}

Most belugas in this study were instrumented with SDR-ST16 satellite-linked time depth recorders (Wildlife
Computers Ltd., Redmond, WA) (Table 1) programmed to transmit for 24 hours every day via the attached ST16 satellite radio transmitter (Telonics, Mesa, AZ). In 2001, some whales were instrumented with SPOT 2 tags (satellite position only tags, Wildlife Computers), which transmitted every 10 days for 24 hours. All whales were captured with nets deployed from a boat, using a modified encirclement technique (Ferrero et al., 2000; Orr et al., 2001). ST16 tags contained a pressure transducer, a conductivity sensor, two or four C-cell batteries, and a microprocessor cast in epoxy. SPOT 2 tags had two M1 batteries and did not have pressure transducers. The tags were attached to whales through the dorsal ridge by means of two or three Monel cables (cast with epoxy into the tag) bolted with nylon nuts and washers to both ends of three pins. During the second half of 2001 and all of 2002, smooth 3/8" pins with perpendicular holes for the cable to pass though were used.

Tagged belugas were tracked using the ARGOS Data Location and Collection System. Tags transmitted ultrahigh frequency messages, which were received by $\mathrm{Na}-$ tional Oceanic and Atmospheric Administration (NOAA) polar orbiting satellites. Locations were determined by Service ARGOS from the Doppler shift of the tag signal frequency that occurs during the satellite's pass overhead (Harris et al., 1990). ARGOS-acquired locations were coded by predicted accuracy. Locations were assigned to one of seven location classes (LC $0-3, \mathrm{~A}, \mathrm{~B}$, and Z). Location classes 1, 2, and 3 (LC 1-3) have a predicted standard error of $1.0,0.35$, and $0.15 \mathrm{~km}$, respectively. Location classes $0, \mathrm{~A}, \mathrm{~B}$, and $\mathrm{Z}$ have no predicted accuracy. Only locations in LC $1-3$ were used for this analysis, and locations on land were eliminated. To minimize autocorrelation bias, average daily positions were calculated for each individual from all good-quality positions received in one day. These positions were used to estimate travel distance and speeds (assuming travel in a straight line from each good-quality ARGOS location to the next).

We calculated the probable area use in each month for the $95 \%, 75 \%$, and $50 \%$ fixed-kernel home ranges, using least squares cross-validation with the ESRI ArcView 


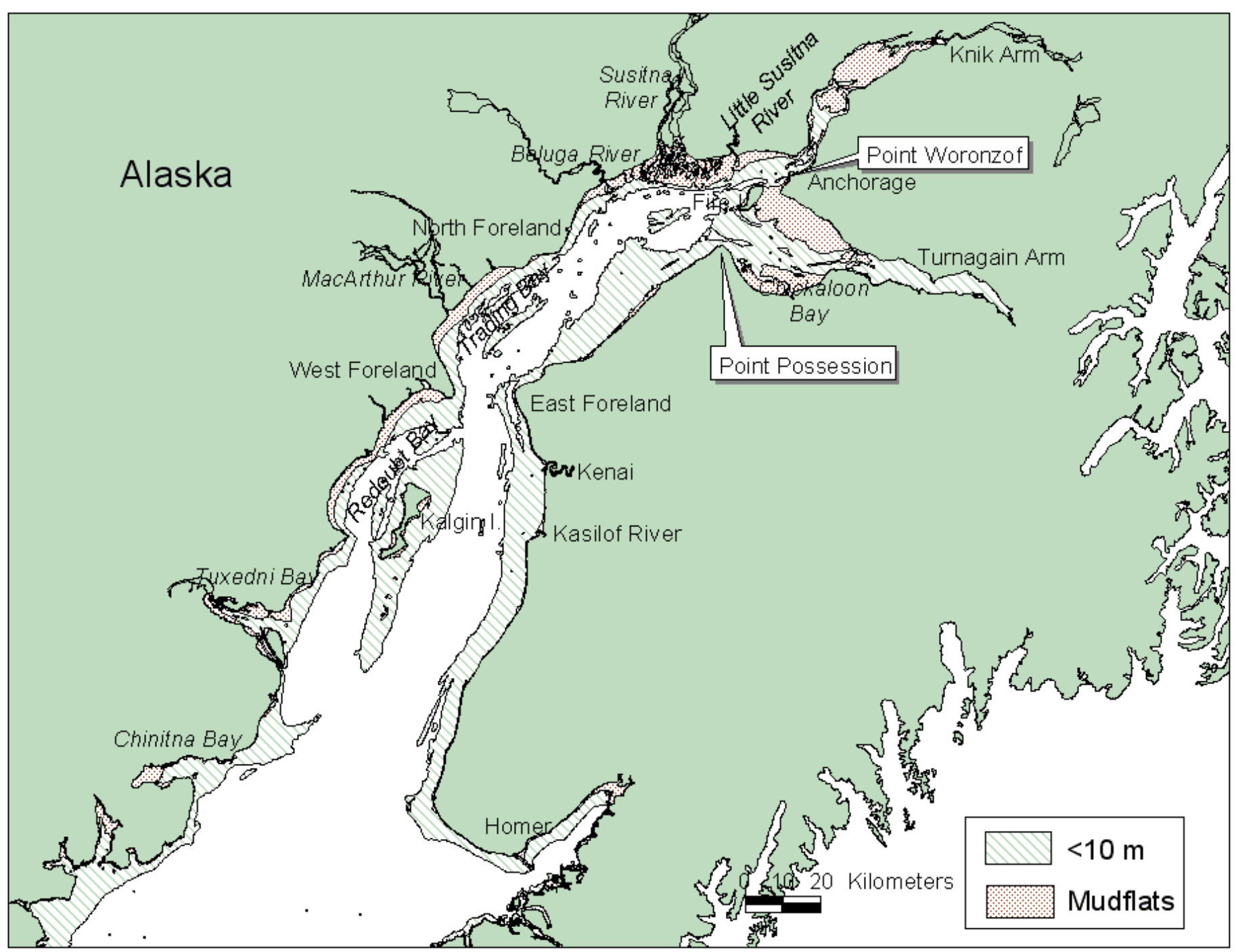

FIG. 1. Map of Cook Inlet, Alaska, showing localities mentioned in text. Dotted areas represent mud flats (exposed at low tide), and hatched areas represent depths of less than $10 \mathrm{~m}$ at low tide.

Animal Movement extension (Hoodge and Eichenlaub, 1997). We pooled whale positions from all three years by month and estimated the total home range $\left(\mathrm{km}^{2}\right)$ in each region $(95 \%, 75 \%$, and $50 \%$ probability) after subtracting the area of overlapping land.

\section{RESULTS}

Fourteen belugas were captured and satellite-tagged in upper Cook Inlet in Knik Arm or near the Susitna Delta between late July and early September 2000-02 (Fig. 1). Two whales were tagged in September 2000, five in late July to early August 2001, and six in early August 2002. Ten whales were instrumented with ST16 tags and four with SPOT2 tags. Of the 14 belugas, seven were males (four white adults and three gray subadults) and seven were females (five adults, one gray-white subadult, and one gray juvenile) (Table 1). The 14 tags transmitted for an average of 132 days $(\mathrm{SD}=73)$ providing 19 to 2254 total locations per tag (Table 2). Tag durations ranged from 2 to 240 days. Four tags transmitted for over 200 days, providing good-quality positions for the entire winter into the end of March. Good-quality positions received for all whales fell into quality categories as $50 \% \mathrm{LC} 1,35 \% \mathrm{LC}$ 2 , and $15 \%$ LC 3 (Table 2).

\section{General Distribution}

All belugas tagged in this study remained in Cook Inlet for the entire period they were tracked. During summer and autumn, whales were concentrated in rivers and bays in upper Cook Inlet; during winter, they were more dispersed and located farther offshore. When in the upper inlet, whales made rapid movements between distinct bays or river mouths. Often they remained stationary in one area for many weeks and then moved abruptly to another area (within a day). In summer and early autumn, whales traveled back and forth between Knik Arm (Eagle River), Chickaloon Bay (Chickaloon River), and upper Turnagain 
TABLE 2. Number of good-quality (LC 1-3) locations obtained from each tag. Total distance traveled by each whale and average travel distance per day are based on straight-line distance between good-quality average daily positions, reported in kilometers.

\begin{tabular}{|c|c|c|c|c|c|c|}
\hline Tag ID & Total \# of Locations & $\%$ LC 1 & $\%$ LC 2 & $\% \operatorname{LC} 3$ & $\begin{array}{c}\text { Total Distance Traveled } \\
\qquad(\mathrm{km})\end{array}$ & $\begin{array}{l}\text { Average Distance Traveled per Day } \\
\text { (Min-Max) }\end{array}$ \\
\hline CI-0001 & 1293 & 64 & 27 & 10 & 1267 & $11 \quad(1-49)$ \\
\hline CI-0002 & 577 & 72 & 20 & 8 & 1769 & $16(0.5-58)$ \\
\hline CI-0101 & 56 & 54 & 32 & 14 & 220 & $20(0.8-53)$ \\
\hline CI-0102 & 112 & 34 & 44 & 22 & 275 & $16(0.3-54)$ \\
\hline CI-0103 & 60 & 45 & 43 & 12 & 566 & $20(0.6-97)$ \\
\hline CI-0105 & 90 & 63 & 27 & 10 & 771 & $24(1.1-143)$ \\
\hline CI-0106 & 1074 & 43 & 41 & 16 & 1221 & $13(0.4-62)$ \\
\hline CI-0107 & 2254 & 49 & 36 & 15 & 2203 & $11(0.2-72)$ \\
\hline CI-0201 & 735 & 41 & 38 & 21 & 1482 & $16(0.3-79)$ \\
\hline CI-0203 & 157 & 53 & 32 & 15 & 695 & $30 \quad(7-75)$ \\
\hline CI-0205 & 812 & 53 & 31 & 17 & 3363 & $19(0.8-78)$ \\
\hline CI-0206 & 970 & 49 & 35 & 15 & 3576 & $18 \quad(0.7-69)$ \\
\hline CI-0207 & 19 & 37 & 42 & 21 & 11 & - \\
\hline CI-0208 & 804 & 49 & 34 & 17 & 3650 & $19(0.4-106)$ \\
\hline Average (SD) & 643 & 50 & 35 & 15 & 1505 & - \\
\hline
\end{tabular}

Arm, although some whales also spent time offshore $(>20 \mathrm{~km})$. Whales traveled frequently and rapidly between these localities, moving either to the east or to the west of Fire Island, past Point Woronzof and the Port of Anchorage. One individual tracked in 2001 (CI-0106, Fig. 2) moved back and forth (between Knik Arm, Chickaloon Bay/Turnagain Arm, and offshore) seven times in a threemonth period.

Dispersal increased in late autumn, as whales traveled longer distances and visited more southerly points in Cook Inlet. From December through March, whales were located primarily offshore and ranged widely in upper and mid Cook Inlet. Movements were less focused on any particular area and were more broadly, or what appeared to be randomly, distributed. Positions for whales were received as late as 30 March in both 2002 and 2003 (Figs. 3a-c), and no movements out of Cook Inlet occurred through the winter.

\section{Travel Distance and Monthly Area Use}

Daily travel distances for individuals ranged between 11 and $30 \mathrm{~km}$ per day (i.e., sum of straight-line distances between sequential positions), and total distance traveled was on average $1505 \mathrm{~km}(\mathrm{SD}=1256$, range $=11-3650 \mathrm{~km}$; Table 2). The longest distance traveled was $3650 \mathrm{~km}$ between August and March (CI-0208, Table 2). Travel distance increased in the late fall and winter when whales were using offshore areas.

Area use in August (encompassing 95\% of locations) was the most limited of all months (approximately $982 \mathrm{~km}^{2}$; Fig. 4a). Belugas were concentrated in Knik Arm near Eagle River, along the Little Susitna River Delta, or near Fire Island, Point Possession, and the shallow tidal estuary of Turnagain Arm. None of the tagged whales used the Susitna River during this period. Approximately 50-75\% of the recorded locations in August were in Knik Arm, concentrated near Eagle River. In September, belugas continued to use Knik Arm and increased use of the
Susitna Delta, Turnagain Arm, and Chickaloon Bay, extending use along the west coast of the upper inlet to the Beluga River, north of North Foreland. The 95\% probability area use increased to $1605 \mathrm{~km}^{2}$, but the $50-75 \%$ probability area use remained similar to that in August (Fig. 4b, Table 3).

In October, whales used coastal regions and ranged widely down the inlet (Fig. 4c). The most southerly points in Cook Inlet were reached during this month, including Chinitna Bay (visited by two whales in 2001 and 2002) and Tuxedni Bay (visited by one whale in 2002). Whales continued to use Knik Arm, Turnagain Arm, and Chickaloon Bay, with higher probability of occurrence $(75 \%)$ in Chickaloon Bay and Trading Bay (MacArthur River) (Fig. 4c). In October, the 95\% kernel area use nearly doubled (to $2945 \mathrm{~km}^{2}$; Table 3).

In November, distribution was similar to that in September (ranging between Knik Arm, Fire Island, and Turnagain Arm); however, the 50\% and $75 \%$ kernels increased (nearly doubled) to include all of Knik Arm and a larger region in Chickaloon Bay. During this period, the $95 \%$ kernel area use moved northward $\left(2013 \mathrm{~km}^{2}\right)$ (Fig. 4d). In December, whales abruptly moved offshore, away from concentration areas in upper Cook Inlet. Locations were broadly distributed and scattered. The 95\% kernel again doubled to $4366 \mathrm{~km}^{2}$ (Fig. 4e), with locations distributed throughout the entire upper inlet. Areas with kernel probability of $75 \%$ and $50 \%$ also increased relative to earlier months in the year (Table 3).

The pattern of increased offshore area use continued in January, with even less frequent occurrence in the upper inlet. Kernels also shifted south (50-95\% probabilities), with minimal use of Knik or Turnagain Arms (3948 km²; Fig. 4f). Movements in February and March were similar to January movements, with little use of upper inlet focal areas and broad use of the central offshore waters. Whales ranged most widely during these two months, covering approximately $5400 \mathrm{~km}^{2}$ (Table 3, Fig. $4 \mathrm{~g}-\mathrm{h}$ ) and visiting Knik and Turnagain Arms despite dense sea-ice coverage (>90\%). 


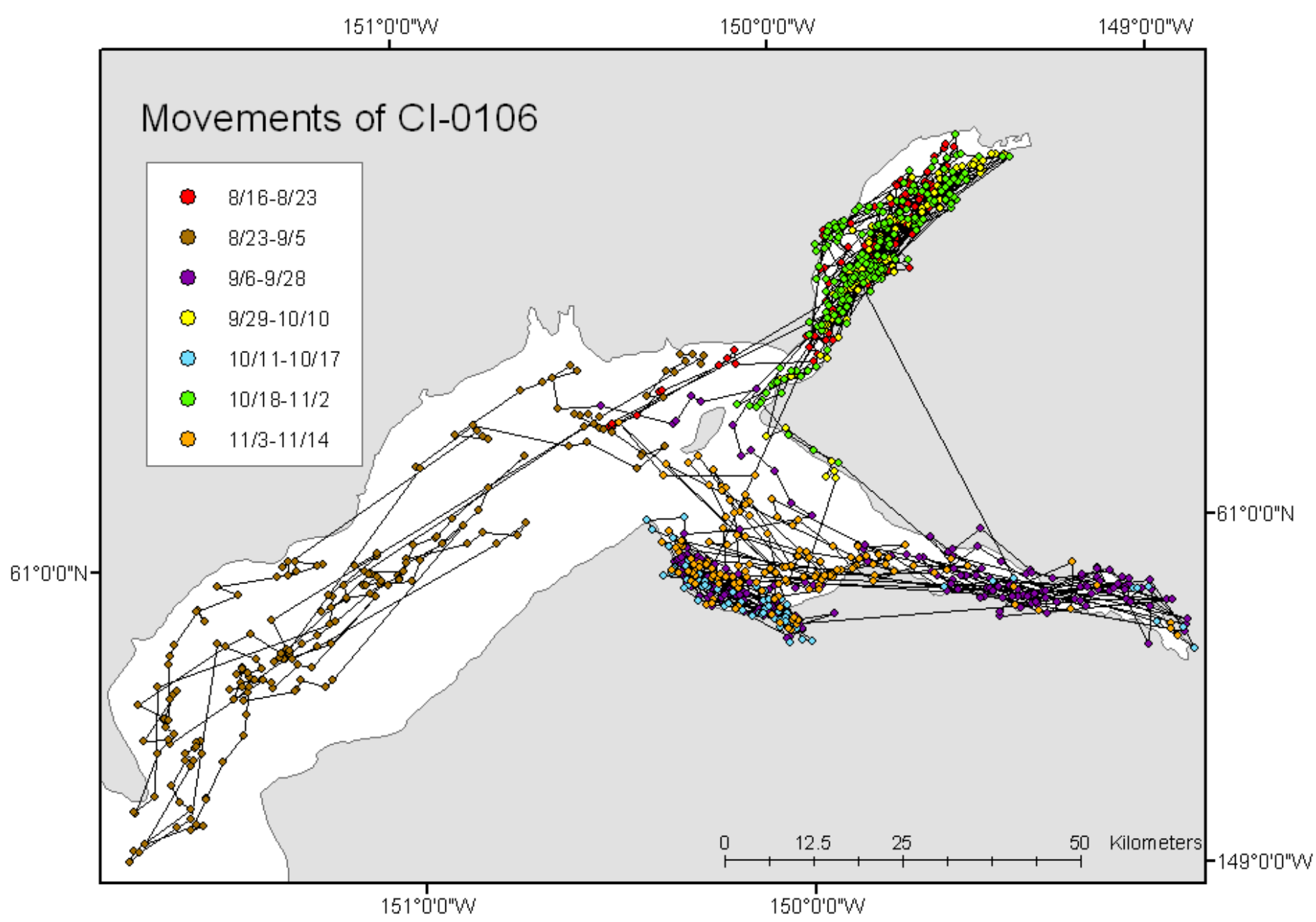

FIG. 2. Movements in upper Cook Inlet for beluga CI-0106 between August and November 2001. Each color represents a stationary period in a particular area, generally at river mouths or bays. Note the rapid shifts between areas in the upper Inlet, often occurring within a single day, particularly the movements between the Knik Arm and Turnagain Arm/Chickaloon Bay areas.

\section{Differences with Year, Age, and Sex}

In general, little variation was observed in areas visited by whales over the three-year study period. Interannual differences were generally due to the timing of movements between concentration points. Whales tagged in $2000(n=2)$ remained in the upper inlet for nearly the entire period they were tracked though January 2001 (Fig. 3a). Whales tagged in $2001(n=6)$ and $2002(n=6)$ ranged more widely than those tagged in 2000 and used mid-inlet waters frequently (Fig. 3b). However, the choice of focal areas and timing of the shift offshore in winter were similar to those of whales tagged in 2000. The most southerly movements were made by four animals. Adult female CI-0105 spent the first two weeks of September in Chinitna Bay, and adult male CI-0201 also visited Chinitna Bay and then moved nearly three-quarters of the way down the west coast of Cook Inlet to Tuxedni Bay. Other extreme southern movements were made by two subadult female belugas (CI-0206 and CI 0208) that visited the Kenai and Kasilof rivers at the end of February.

Neither age class nor sex appeared to influence the propensity for offshore area use or occurrence in mid-inlet waters. Both adult and subadult animals had similar patterns of movement across months and seasons, and both males and females visited extreme southerly points, as well as using similar offshore and focal areas.

\section{DISCUSSION}

None of the belugas tagged in this study (several of which were tracked for up to seven months, or through March) left Cook Inlet. The movements of the tagged animals are consistent with the hypothesis that belugas remain in Cook Inlet throughout the year. Although the tagged individuals may not demonstrate the complete range of variation in movements for this population, the consistent patterns and high site fidelity are likely a good representation of population patterns. As population density increases, it is possible that these belugas will use more habitat and perhaps a greater range of the inlet.

The range of all whales increased after October and continued to increase into late autumn, likely because of a decrease in the concentration of fish runs at the river mouths in the upper inlet. The offshore locations, lack of 

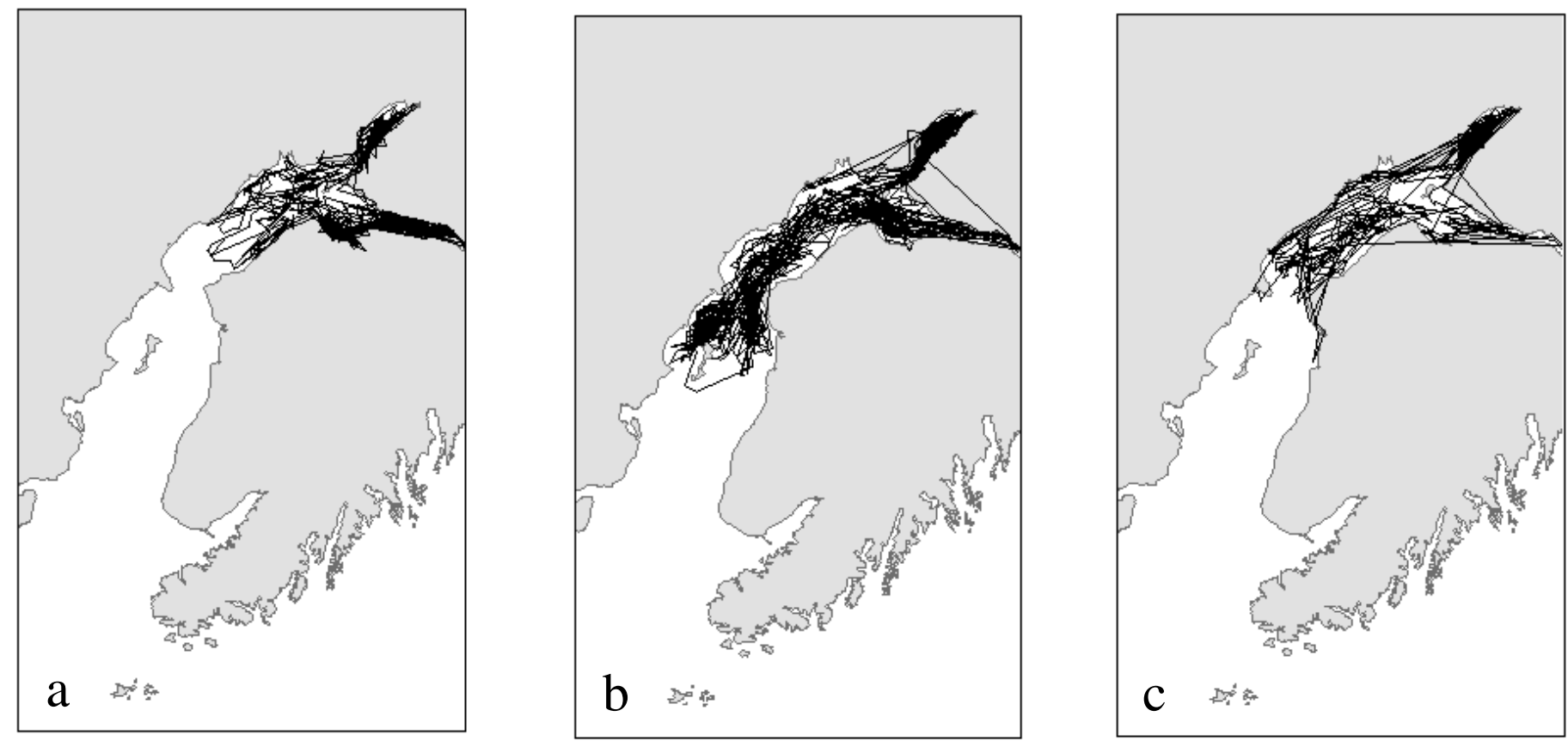

FIG. 3a-c. Movement track lines derived from good-quality positions received from three belugas tagged in 2000 (a), 2001 (b), and 2002 (c). Whales were tracked from late August to as late as March the following year.

TABLE 3. Estimates of monthly population area use $\left(\mathrm{km}^{2}\right)$ based on kernel density calculations. Estimates are derived from all daily average positions from each whale in a given month.

\begin{tabular}{lccc}
\hline \hline Month & $95 \%$ Kernel & $75 \%$ Kernel & $50 \%$ Kernel \\
\hline August & 982 & 233 & 163 \\
September & 1605 & 259 & 197 \\
October & 2945 & 750 & 230 \\
November & 2013 & 678 & 352 \\
December & 4366 & 3108 & 1692 \\
January & 3948 & 1966 & 773 \\
February & 5475 & 2798 & 1073 \\
March & 5366 & 2961 & 1365 \\
\hline \hline
\end{tabular}

focal area use, and occupation of ice-covered waters, together with the greatly reduced time belugas spent at the surface in winter (Hobbs, 2004), probably affected sighting rates in winter. Most likely the dispersal into the middle inlet in late autumn and early winter represents a different foraging tactic, since whales must find prey in mid or bottom waters rather than at river mouths when seasonal salmon runs have ceased. Fish communities are strongly influenced by temperature and salinity gradients. In lower Cook Inlet, mid-water trawls have documented that three species-Pacific sand lance (Ammodytes hexapterus), Pacific herring (Clupea pallasi), and juvenile walleye pollock (Theragra chalcogramma) - account for nearly $98 \%$ of the fish community. Farther north in the inlet, where influx of oceanic water is lower, fish communities show higher species diversity but are less rich in lipids (Abookire and Piatt, 2005). Although there were occasional visits to extreme southerly bays (Fig. 3c), belugas remained in the mid- to upper inlet, north of Kalgin Island, at least through March. Aerial surveys conducted in late May and early June (Rugh et al., 2000, 2005) found nearly the entire population in the far reaches of the upper inlet; therefore, it is unlikely that whales leave Cook Inlet for the short period between March and June.

The distribution of Cook Inlet belugas through the summer and autumn appears to be determined by feeding opportunities. Belugas routinely concentrate over the Susitna River delta in early summer (Rugh et al., 2000, 2005). Alaskan Natives report that the whales feed there on migrating fish, predominantly eulachon (Thaleichthys pacificus) and Pacific salmon (Huntington, 2000), which have been identified in stomach contents of harvested whales (Moore et al., 2000). The patterns and timing of eulachon and salmon runs seem to affect beluga feeding behavior and likely have the strongest influence on the shifts in movements of whales in Cook Inlet (Moore et al., 2000). Later in the autumn, prey species are more dispersed (Moulton, 1997). Prey dispersal reduces dense group feeding behavior of whales at river mouths and likely influences their offshore area use (Moore et al., 2000). The spatial dispersal of prey means that winter feeding areas may be critical to the health and size of the beluga population. The small-scale, directed movements between river mouths or bays observed until late autumn in this study corroborate these generalized patterns. It is likely that shifts in movements between Knik Arm, Turnagain Arm, and Chickaloon Bay represent behavioral changes related to fish runs in these rivers or associated tributaries (Moore et al., 2000). In this study, we observed little intensive use of the Susitna River delta during late summer, although daily use has been observed in earlier summer months (Rugh et al., 2000). It is possible that fish runs in the Susitna area may provide a better feeding opportunity prior to August. However, it is difficult to 

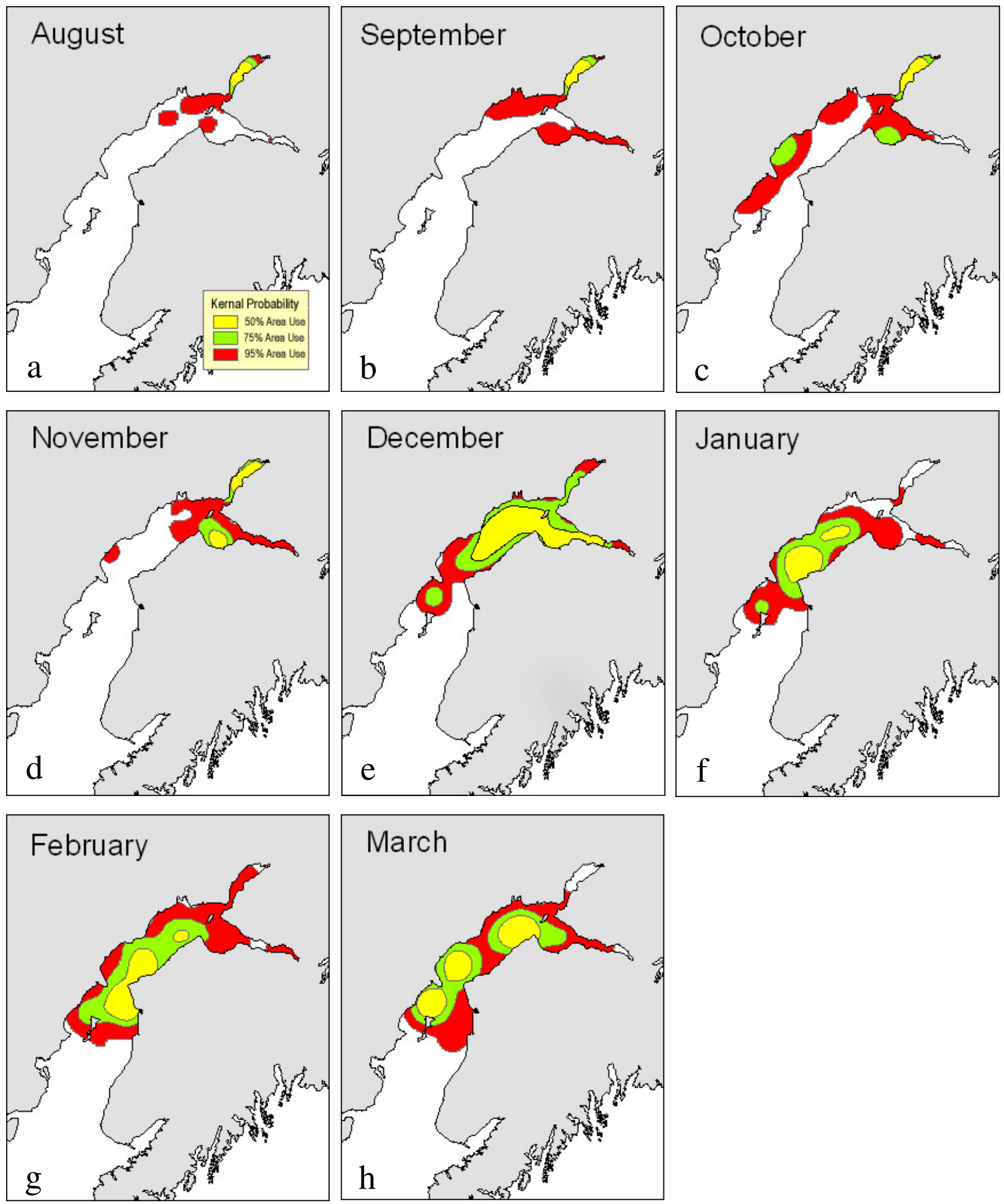

FIG. 4a-h. Kernel probability estimates by month (August-March) for area use in Cook Inlet, derived from average daily good-quality positions for all whales in a given month. The red area (95\% probability) encompasses the green $(75 \%)$ and yellow $(50 \%)$ regions. Note the large increase in total area use and offshore locations beginning in December and continuing through March. Overall habitat use may exceed area encompassed in 95\% kernel concentration areas. 
make this quantitative link (relative to both spatial and temporal changes in fish runs in Cook Inlet) because salmon runs vary from drainage to drainage and changes in commercial and sport fishery patterns may mask trends in salmon escapement (Moore et al., 2000).

The pattern of movement between river mouths that we observed in late summer and early autumn was similar to that observed by Lydersen et al. (2001) in summer and fall near Svalbard, where belugas spent over $60 \%$ of their time highly localized either in front of glaciers with large outflows of freshwater or along specific areas of the coast. When whales moved from one place to another, they traveled in shallow water along the coast in a rapid and directed manner. Lydersen et al. (2001) suggested that the freshwater areas in front of glaciers contain significant sources of prey, and beluga movements were simply a reflection of transport between productive areas of interest.

Similar resident behavior during fall and winter months has been observed for beluga whales in Cumberland Sound, Baffin Island, Canada (P.R. Richard, pers. comm. 2003) and in St. Lawrence Inlet (Kingsley, 2002). Studies of these populations, combined with the results reported here, indicate that some beluga populations can be considered "year-round residents" and do not make the annual long-distance migrations between summering and wintering grounds observed for other beluga populations (Richard et al., 1998, 2001 a, b; Martin and Smith, 1999; Suydam et al., 2001).

Tidal fluctuations in Cook Inlet $(9 \mathrm{~m})$ are among the most extreme in the world (second only to those in Canada's Bay of Fundy), and the tidal range produces extreme tidal currents ranging from $2-4 \mathrm{~m} / \mathrm{second}$ (Mulherin et al., 2001). Tides have been documented to influence beluga movements in other areas (Kleinenberg et al., 1964; Caron and Smith, 1990). Belugas in Cook Inlet have been observed moving into the upper reaches of the inlet during flood tide and departing during ebb tide (Moore et al., 2000; Hobbs, 2004). The variability in the temporal reception of ARGOS locations, positional error, and small areas of beluga use relative to tidal fluctuation did not allow for robust detailed examination of movements and tidal fluctuations. However, it is likely that fine-scale movements within a 24-hour period are closely linked to tide. Tidal movement corridors are important to Cook Inlet belugas, as movements with the tides occur daily, or twice daily, and allow access to feeding and nursery areas.

Ice cover in Cook Inlet is seasonal, forming in the fall (generally October) and disappearing completely in the spring. By December, about half the inlet north of the Forelands is normally covered in pancake ice (up to $10 \mathrm{~cm}$ thick) and thin ice (30-70 cm thick) ranging in concentration primarily from open (10\%) to close pack (70\% to 80\%) (Mulherin et al., 2001). The ice extent and thickness increase through late January and February, reaching maximums in mid-February to early March. During colder winters, the ice may extend into the lower inlet south of Chinitna Bay on the west side and to approximately $60^{\circ} \mathrm{N}$ (north of Homer) on the east side
(Mulherin et al., 2001). It has been well documented that belugas can tolerate extreme concentrations of sea ice. Suydam et al. (2001) reported that satellite-tagged belugas traveled from the northwest coast of Alaska to $80^{\circ} \mathrm{N}$ through sea-ice concentrations as high as $\sim 100 \%$. Moore et al. (2000) reported that belugas in the Alaska High Arctic selected a range of sea ice concentrations, from $10 \%$ ice cover to $100 \%$ ice cover, depending on the season and behavior. In the present study, sea ice did not appear to influence the movements of whales in late fall, as whales used the upper inlet and Knik or Turnagain Arms even during winter months (December to March), when they were filled with more than $90 \%$ sea ice.

Killer whale (Orcinus orca) predation on belugas in Cook Inlet has been a subject of recent concern (Shelden et al., 2003), and distributions of belugas, in general, have been suggested as predation avoidance adaptations (Sergeant and Brodie, 1969; Shelden et al., 2003). During this study, five sightings of killer whales were reported while tagged belugas were being monitored (in 2000 and 2002). At the exact time of two of these five killer whale sightings, at least one tagged beluga was in the direct vicinity of killer whales, and possibly even in the same beluga pod where predation events were documented (see Fig. 2, 23-26 September 2000). Killer whale predation on belugas in Cook Inlet appears to be random and no clear seasonal patterns have been identified (Shelden et al., 2003), leaving no conclusive evidence that summer distribution of belugas is determined by killer whale occurrence. It is important to note, however, that detection of predation events or beluga carcasses may be hampered by sea ice.

The cohesion of beluga groups in Cook Inlet observed in early-summer aerial surveys means that the whales interact with each other and may be behaving cooperatively. In aerial observations during the past 10 years, this cooperation has been especially notable when beluga groups moved together away from shallow water during a falling tide and traveled together up narrow channels during a flooding tide (Rugh et al., 2005). It is highly likely that the recorded movements of tagged whales are representative of group or population movements. The killer whale predation event in September 2000, when a pod of 40-50 belugas was observed in the same area indicated by satellite positions from the tagged whales, provides further evidence for this conclusion.

The information collected during this study documents late summer, fall, and winter distribution of belugas in Cook Inlet and quantifies spatial changes in monthly distribution. The data presented here do not document areas and habitat that were used by the pre-exploited population or areas that would be used by a larger population in the future as indicated by historical sightings (Mahoney and Shelden, 2000). The present small resident population appears to change behavior seasonally, and these shifts are likely related to changes in the distribution of prey. The resident nature of these whales requires sound management that includes consideration of habitat alteration and anthropogenic impacts within their very restricted range. 


\section{ACKNOWLEDGEMENTS}

This manuscript was improved by comments from R. Angliss, D. DeMaster, G. Duker, S. Moore, K. Shelden, B. Fadely, D. Rugh, and three anonymous reviewers. L. Hobrecht assisted in field preparations and joined the authors, together with D. Baird, K. and R. Dimmick, C. Goode, W. Gossweiler, B. Hanson, N. Lord, P. Merryman, G. O'Corry-Crowe, R. Olson, C. Saccheus, D. Segars, B. Walker, L. Quakenbush and several others, during tagging operations. R. Ferrero initially developed the capture methods for Cook Inlet beluga. Funding for this project was provided by the Office of Protected Resources, National Marine Fisheries Service; work was conducted under NMFS Permits 957 and 782-1438 (Amendment No. 3).

\section{REFERENCES}

ABOOKIRE, A.A., and PIATT, J.F. 2005. Oceanographic conditions structure forage fish communities into lipid-rich and lipid-poor communities in lower Cook Inlet, Alaska, USA. Marine Ecology Progress Series 287:229-240.

CALKINS, D.G. 1983. Marine mammals of lower Cook Inlet and the potential for impact from Outer Continental Shelf oil and gas exploration, development, and transport. Research Unit 243. In: Environmental Assessment of the Alaskan Continental Shelf. Final Reports of the Principal Investigators 20. Juneau, Alaska: National Oceanic and Atmospheric Administration, U.S. Department of Commerce. 171-263.

CARON, L.M.J., and SMITH, T.G. 1990. Philopatry and site tenacity of belugas, Delphinapterus leucas, hunted by Inuit at the Nastapoka estuary, eastern Hudson Bay. In: Smith, T.G., St. Aubin, D.J., and Geraci, J.R., eds. Advances in research on the beluga whale, Delphinapterus leucas. Canadian Bulletin of Fisheries and Aquatic Sciences 224:69-79.

FERRERO, R.C., MOORE, S.E., and HOBBS, R.C. 2000. Development of beluga whale capture and satellite tagging protocol in Cook Inlet, Alaska. Marine Fisheries Review 62(3): $112-123$.

HANSON, D.J., and HUBBARD, J.D. 1999. Distribution of Cook Inlet beluga whales (Delphinapterus leucas) in winter. Outer Continental Shelf (OCS) Study MMS 99-0024. Available from the National Marine Mammal Laboratory, 7600 Sand Point Way NE, Seattle, Washington 98115. 30 p. + appendices.

HARRIS, R.B., FANCY, S.G., DOUGLAS, D.C., GARDNER, G.W., ARMSTRUP, S.C., McCABE, T.R., and PANK, L.F. 1990. Tracking wildlife by satellite: Current systems and performance. U.S. Fish and Wildlife Technical Report 30. Washington D.C.: U.S. Fish and Wildlife Service, United States Department of the Interior. $52 \mathrm{p}$.

HEIDE-JØRGENSEN, M.P., RICHARD, P.R., and ROSINGASVID, A. 1998. Dive patterns of belugas (Delphinapterus leucas) in waters near eastern Devon Island. Arctic 51(1): $17-26$.

HILL, P.S. 1996. The Cook Inlet stock of beluga whales: A case for co-management. M.S. thesis, University of Washington, Seattle. $107 \mathrm{p}$.
HOBBS, R.C. 2004. Seasonal changes in diving behavior of belugas in the sub-Arctic estuary of Cook Inlet, Alaska. Unpublished ms. Available from the National Marine Mammal Laboratory, 7600 Sand Point Way NE, Seattle, Washington 98115.

HOBBS, R.C., RUGH, D.J., and DeMASTER, D.P. 2000. Abundance of beluga whales in Cook Inlet, Alaska, 1994-2000. Marine Fisheries Review 62(3):37-45.

HOODGE, P.N., and EICHENLAUB, B. 1997. Animal movement extension to Arcview Version 1.1. Anchorage: Alaska Biological Science Center, U.S. Geological Survey.

HUBBARD, J.D., HANSEN, D.J., and MAHONEY, B.A. 1999. Winter sighting of beluga whales (Delphinapterus leucas) in Yakutat-Disenchantment Bay, Alaska. Arctic 52(4):411-412.

HUNTINGTON, H.P. 2000. Traditional knowledge of the ecology of belugas, Delphinapterus leucas, in Cook Inlet, Alaska. Marine Fisheries Review 62(3):134-140.

KINGSLEY, M.C.S. 2002. Status of the belugas of the St. Lawrence estuary, Canada. In: Heide-Jørgensen, M.P., and Wiig, Ø., eds. Belugas in the North Atlantic and the Russian Arctic. NAMMCO Scientific Publications 4:239-258.

KINGSLEY, M.C.S., GOSSELIN, S., and SLENO, G.A. 2001. Movements and dive behavior of belugas in northern Quebec. Arctic 54(3):262-275.

KLEINENBERG, S.E., YABLOKOV, A.V., BEL'KOVICH, V.M., and TARASEVICH, M.N. 1964. Beluga (Delphinapterus leucas): Investigation of the species. Moscow: Akad. Nauk. $376 \mathrm{p}$.

LAIDRE, K.L., SHELDEN, K.E.W., RUGH, D.J., and MAHONEY, B.A. 2000. Distribution of beluga whales and survey effort in the Gulf of Alaska. Marine Fisheries Review 62(3):27-36.

LYDERSEN, C., MARTIN, A.R., KOVACS, K.M., and GJERTZ, I. 2001. Summer and autumn movements of white whales Delphinapterus leucas in Svalbard, Norway. Marine Ecology Progress Series 219:265-274.

MAHONEY, B.A., and SHELDEN, K.E.W. 2000. Harvest history of belugas, Delphinapterus leucas, in Cook Inlet, Alaska. Marine Fisheries Review 62(3):124-133.

MARTIN, A.R., and SMITH, T.G. 1992. Deep diving in wild, freeranging beluga whales, Delphinapterus leucas. Canadian Journal of Fisheries and Aquatic Sciences 49:462-468.

. 1999. Strategy and capability of wild belugas, Delphinapterus leucas, during deep, benthic diving. Canadian Journal of Zoology 77:1783-1793.

MARTIN, A.R., HALL, P., and RICHARD, P.R. 2001. Dive behavior of belugas (Delphinapterus leucas) in the shallow waters of western Hudson Bay. Arctic 54(3):276-283.

MOORE, S.E., SHELDEN, K.E.W., LITZKY, L.K., MAHONEY, B.A., and RUGH, D.J. 2000. Beluga whale, Delphinapterus leucas, habitat associations in Cook Inlet, Alaska. Marine Fisheries Review 62(3):60-80.

MOULTON, L.L. 1997. Early marine residence, growth, and feeding by juvenile salmon in northern Cook Inlet, Alaska. Alaska Fisheries Research Bulletin 4:154-177.

MULHERIN, N.D., TUCKER, W.B., III, SMITH, O.P., and LEE, W.J. 2001. Marine ice atlas for Cook Inlet, Alaska. ERDCCRREL Technical Report 01-10. Hanover, New Hampshire: U.S. Army Corps of Engineers, Engineer Research and 
Development Center, Cold Regions Research and Engineering Laboratory. $147 \mathrm{p}$.

O'CORRY-CROWE, G.M., SUYDAM, R.S., ROSENBERG, A., FROST, K.J., and DIZON, A.E. 1997. Phylogeography, population structure and dispersal patterns of the beluga whale Delphinapterus leucas in the western Nearctic revealed by mitochondrial DNA. Molecular Ecology 6:955-970.

ORR, J.R., JOE, R., and EVIC, D. 2001. Capturing and handling of white whales (Delphinapterus leucas) in the Canadian Arctic for instrumentation and release. Arctic 54(3):299-304.

RICHARD, P.R., HEIDE-JØRGENSEN, M.P., and ST. AUBIN, D. 1998. Fall movements of belugas (Delphinapterus leucas) with satellite-linked transmitters in Lancaster Sound, Jones Sound, and northern Baffin Bay. Arctic 51(1):5-16.

RICHARD, P.R., HEIDE-JØRGENSEN, M.P., ORR, J.R., DIETZ, R., and SMITH, T.G. 2001a. Summer and autumn movements and habitat use by belugas in the Canadian High Arctic and adjacent areas. Arctic 54(3):207-222.

RICHARD, P.R., MARTIN, A.R., and ORR, J.R. 2001b. Summer and autumn movements of belugas of the eastern Beaufort Sea stock. Arctic 54(3):223-236.
RUGH, D.J., SHELDEN, K.E.W., and MAHONEY, B.A. 2000. Distribution of beluga whales in Cook Inlet, Alaska, during June/July 1993-99. Marine Fisheries Review 62(3):6-21.

RUGH, D.J., MAHONEY, B.A., and SMITH, B.K. 2004. Aerial surveys of beluga whales in Cook Inlet, Alaska, between June 2001 and June 2002. NOAA Technical Memorandum NMFSAFSC-145. $44 \mathrm{p}$.

RUGH, D.J., SHELDEN, K.E.W., SIMS, C.L., MAHONEY, B.A., SMITH, B.K., LITZKY, L.K., and HOBBS, R.C. 2005. Aerial surveys of beluga whales in Cook Inlet, Alaska, June 2001, 2002, 2003, 2004. NOAA Technical Memorandum NMFSAFSC-149. $71 \mathrm{p}$.

SERGEANT, D.E., and BRODIE, P.F. 1969. Body size in white whales, Delphinapterus leucas. Journal of the Fisheries Research Board of Canada 26:2561-2580.

SHELDEN, K.E.W., RUGH, D.J., MAHONEY, B.A., and DAHLHEIM, M.E. 2003. Killer whale predation on belugas in Cook Inlet, Alaska: Implications for a depleted population. Marine Mammal Science 19:529-544.

SUYDAM, R.S., LOWRY, L.F., FROST, K.J., O'CORRYCROWE, G.M., and PIKOK, D., Jr. 2001. Satellite tracking of eastern Chukchi Sea beluga whales into the Arctic Ocean. Arctic 54(3):237-243. 